\title{
The power of maps and participatory approaches: the use of social cartography in the territorial representation of rural settlements
}

\author{
O poder dos mapas e as abordagens participativas: o uso da cartografia \\ social na representação territorial dos assentamentos rurais \\ El poder de los mapas y los enfoques participativos: el uso de la cartografía \\ social en la representación territorial de los asentamientos rurales
}

\author{
Cleiton Silva Ferreira Milagres ${ }^{1}$ \\ José Ambrósio Ferreira Neto \\ Diego Neves de Sousa ${ }^{3}$
}

\begin{abstract}
Received on 10/16/2018; reviewed and approved on 05/10/2019; approved on 05/27/2019.
\end{abstract} DOI: http://dx.doi.org/10.20435/inter.v21i2.2190

\begin{abstract}
The elaboration of a methodology of social intervention based on a collective work has as proposal to meet the needs of the community, the orientation of the technicians and a better interaction with the institutions that act in the place. In this sense, this article analyzes the development of a participatory methodology that articulates the use of the principles of social cartography. This was applied and validated in a rural settlement for the elaboration of georeferenced participatory maps on territorial representation. It is concluded that this methodology facilitated the empowerment of the participants in the territorial representation of the rural settlement.
\end{abstract}

Keywords: rural development; participative rural diagnosis; georeferenced participatory map; agrarian reform; territorial representation.

Resumo: A elaboração de uma metodologia de intervenção social baseada em um trabalho coletivo tem como proposta atender às necessidades da comunidade, a orientação dos técnicos e uma melhor interação com as instituições que atuam no local. Neste sentido, este artigo analisa o desenvolvimento de uma metodologia participativa que articula o uso dos princípios da cartografia social. Esta foi aplicada e validada em um assentamento rural para a elaboração de mapas participativos georreferenciados sobre a representação territorial. Conclui-se que essa metodologia facilitou o empoderamento dos participantes na representação territorial do assentamento rural.

Palavras-chave: desenvolvimento rural; diagnóstico rural participativo; mapas participativos georreferenciados; reforma agrária; representação territorial.

Resumen: La elaboración de una metodología de intervención social basada en un trabajo colectivo tiene como propuesta atender las necesidades de la comunidad, la orientación de los técnicos y una mejor interacción con las instituciones que actúan en la localidad. En este sentido, este artículo analiza el desarrollo de una metodología participativa que articula el uso de los principios de la cartografía social. Esta fue aplicada y validada en un asentamiento rural para la elaboración de mapas participativos georreferenciados sobre la representación territorial. Se concluye que esa metodología facilitó el empoderamiento de los participantes en la representación territorial del asentamiento rural.

Palabras clave: desarrollo rural; diagnóstico rural participativo; mapas participativos georreferenciados; reforma agraria; representación territorial.

\section{INTRODUCTION}

The structuring of rural settlements was and still is the result of a broad social struggle for land ownership, involving several workers in numerous conflicts, engendering a new social, economic and political organization. Debating about rural settlements and the dynamics of their

\footnotetext{
${ }^{1}$ Universidade Federal do Tocantins (UFT), Araguaína, Tocantins, Brazil.

${ }^{2}$ Universidade Federal de Viçosa (UFV), Viçosa, Minas Gerais, Brazil.

${ }^{3}$ Empresa Brasileira de Pesquisa Agropecuária (Embrapa), Palmas, Tocantins, Brazil.
} 
creation approaches the subject of how the various studies on land reform policy in Brazil have been formulated and, overall, how it is being carried out.

In order to understand the dynamics of creating a rural settlement focusing on collective work in the planning of interventions in the physical environment and the construction of social spaces within a participatory approach are fundamental elements. This leads this study to debate on territorial representation through the traditional knowledge of the communities, because in most of the studies the inclusion of the local population in the cartographic processes is not considered by the Geographic Information Systems (GIS), which reflects only the specialists' point of view.

There are Brazilian experiences in the use of social cartography mainly in traditional communities of the Amazon with the creation and demarcation of extractive reserves and in indigenous lands, however the experiences in agrarian reform projects are rare. More consolidated, experiences in various parts of the world have demonstrated that participatory processes enable empowerment strategies and the use of participatory methodologies have favored the establishment of development practices that address the needs of those involved in the process. The experiences can be cited in Ghana (DWAMENA; BANAYNAL; KEMAUSUOR, 2011); in Uganda (WEBBER, 2014); in Mozambique (KIENBERGER, 2014); in Switzerland (REICHEL, 2014); in Mexico (HILBURN, 2015); in Canada (BERNIER et al., 2016) and in Australia (ROBINSON et al., 2016).

The academic discussions on the subject of rural settlement projects, the theoretical approach to the agrarian matter and access to land is recurrent. However, it is also important to discuss how the government agencies responsible for the land reform policy in the country are creating these projects. Considering that, in legal terms, many of these projects do not take into account the conditions of the physical environment and local participation in the territorial organization, as pointed out by Santos Junior (2007), Soares (2008), Ferreira Neto, Milagres and Sousa (2010), Milagres, Ferreira Neto and Sousa (2013), Milagres, Sousa and Ferreira Neto (2017).

The role of promoting land reorganization and the implementation of rural settlements is carried out by the National Institute of Colonization and Agrarian Reform (Incra), a state agency that alongside with other public and/or private institutions, draws up the Settlement Development Plan (SDP) document that will guide the process of social and productive organization of the projects.

The SDP is an instrument that allows a physical, social and economic portrayal of the area occupied by the beneficiaries of the agrarian reform and, above all, constitutes a planning tool for the Rural Settlement Projects. It involves all phases of the implementation process, starting with the installation of families in the rural settlement area, their effective training and participation in the construction of it and elaboration of the plan, until the complete emancipation and sustainability of the project, obtained with socioeconomic and productive progress.

It is through the SDP that the organization of the space is defined, indicating the areas for housing, production, forest reserve, access roads, among others. In addition, the SPD lists the productive activities to be developed in the rural settlement, the actions necessary for recovering and conserving the environment. The social and basic infrastructure program, all the elaboration of the plan must count on the participation of the settled families.

Thus, the elaboration of an intervention methodology based on a collective work aimed at meeting the needs of the community, the orientation of the technicians and a better interaction with the institutions that work in the place. Consequently, it contributes in the planning of the 
interventions to be delineated within a participatory approach on the use and spatial occupation of family lots in a rural settlement project.

That way, this article analyzes the development of a participative methodology that articulates the use of the principles of social cartography. This was applied and validated in a rural settlement (Itatiaia) for the elaboration of georeferenced participatory maps on territorial representation. Therefore, this work seeks to demonstrate that through social cartography it is possible the community involvement in the production of maps. This allows it to avoid possible distortions in the use of Geographic Information Systems by providing greater empowerment to those involved in decision making through the use of local knowledge.

This article is structured in six parts, the first one being the introduction, the following is presented the use of participatory diagnostics in community development. The third refers to the specificities of social cartography. In the fourth part, the study area is described the physical and social aspects of the Itatiaia settlement project. In the fifth presents the results of the application of the methodology regarding the use of cartography of the physical and social space of the Itatiaia. Finally, the final considerations that summarize the article.

\section{THE USE OF PARTICIPATORY TECHNIQUES IN INTERVENTION PROCESSES IN THE RURAL AREAS}

The dissemination of information, knowledge and the use of technologies are systematically linked by research and development models. Intervention actions have long been restricted to the role of technology transfer, often carried out from top down to bottom up (DINIZ, 2007; MILAGRES et al., 2018).

In the decisions that involve the rural public, for instance, research models that were at first less concerned with establishing a learning process involving the research, the technician and the user are considered.

The proposition made by Chambers (1993) in his work points out that, the actors present in the community are the real agents of their own development, defining in turn a new model for doing research - the Farming First (FF). In this model, the community is called upon to make use of technology according to its capacities and priorities, since the objective is neither to transfer technology to the community, nor to analyze purely and simply by external agents, but rather, to empower the community to learn, adapt and make the best use of technology. That is, local knowledge is unique, being systematized, translated and evaluated for assimilation and incorporation into scientific technical knowledge (DINIZ, 2007).

Gibbon (1994) presents a new model, called Farming Systems Research/Extension (FSR/E), with some suggestions for the process in this context, where research has undergone some transformations, and in the attempt of an interaction between actors. Aiming to overcome misunderstandings as a dynamic interaction in the relations between researcher, extensionist and producer, where the latter plays a role of equal importance in the process. The need for the interdisciplinary approach where the participation of social scientists can interact with researchers of the natural sciences, as well as the need of taking care of the crucial subject, sustainability. It has been placed as a fundamental factor to be considered, facing the environmental problems that have arisen, whether by human action or not, this issue today occupies an important topic of discussion for the adequacy of research and extension models in agrarian activity. 
During the same period that the research models sought to build the efforts for a greater dialogue with the users that would benefit from the proposed innovations, the first manuals of Participative Rural Diagnosis (PRD) emerged in the decade of 70 as a tool that could obtain, in a fast way, new information on life and resources in rural areas. Participatory diagnoses have emerged with a proposition of creating a path to stimulate and support members of social groups in a meaningful space of time, so that they can investigate, analyze and assess their obstacles and chances (BROSE, 2001).

Dias (2006) adds that rural diagnoses appeared as a means to a better understand the processes of promoting development and encouraging participation of beneficiaries of actions. The diagnoses defended the idea that it would not be possible to interfere in a reality without first knowing it. In this case, the introduction of new technologies would depend on their adequacy to the diagnosed reality.

It is noticeable that the use of participatory techniques in the social intervention process and the role accepted or attributed to the external agents that use them, began to gain space in the discussions about the tools used for decision-making in social groups. Participation is being consolidated in the field of method studies and participatory techniques which are instruments widely used in the intervention processes, assisting in the learning process and aiming at social change of the public involved in the actions (MILAGRES; MOURA; FERREIRA NETO, 2014).

In this sense, the PRD has consolidated itself as an important participatory tool for rural communities in favor of development. However, of all the visual methods that have been adopted and succeeded, McCall (2006) adds that participatory mapping - with its many variants and applications- was the most widespread in working with communities, not only in the management of natural resources, but also in many other fields.

According to Andrade and Santamaría (2018) there is a set of methods that have emphasized participatory mapping as an instrument for understanding how communities use space, and for the empowerment of communities to resolve territorial management conflicts. This way of producing maps has encouraged the communities to design and model their territory and resources, deciding what to include, what to delete, and how to modify details.

However Chambers (2006) cautions that there are many ethical issues that present troubling dilemmas regarding empowerment. Questions to be asked: who is empowered and who is disempowered? And, who gains and who loses? The discussion is based on the fact that in the coming years many things will depend on the behavior and attitudes of the facilitators and that, because of their mastery of GIS technologies, partially control the process of translation and transfer of knowledge.

\section{SOCIAL CARTOGRAPHY: THE REPRESENTATION OF THE TERRITORY THROUGH THE COLLECTIVE ELABORATION OF GEOREFERENCED MAPS}

Having the task of involving communities in the production of georeferenced cartograms on the place they live, new tools have arisen in a way that contemplate the representations of the individuals and allow a better understanding of the multiple realities existing in the same community. Through the social cartography, for example, the elaboration of "participative maps" is able to consider the symbolic content present in the identity of the individuals, establishing a field of construction of methodologies and use of technologies that points to a participative 
cartographic approach, creating conditions for social groups to self-map (CADAG; GAILLARD, 2012; MILAGRES; FERREIRA NETO; SOUSA, 2013; WEBBER, 2014; GAILLARD; HORE; CADAG, 2015; ROBINSON et al., 2016).

According to Herrera (2009), social cartography is a conceptual and methodological proposal that allows the construction of a comprehensive knowledge of a territory, using technical and experiential tools in the collective elaboration of maps.

Andrade and Santamaría (2018) clarify that social cartography consists of using the collective elaboration of maps to be able to understand what has happened and occurs in a given territory, as a way of escaping from reality to start looking for processes of change. For the authors, social cartography is a tool that helps in the construction of knowledge through the collective elaboration of maps that unleashes communication processes between those involved in the process and reveals different types of knowledge that are mixed to arrive at a collective image of the territory.

It can be seen, therefore, that social cartography can effectively offer the community a better discussion about territorial planning, unlike conventional (institutional) cartography that privileges the hierarchical and more centralizing character. In the Table 1 shows a comparison between social cartography and conventional cartography.

Table 1 - Comparative analysis of Social Cartography and Conventional Cartography

\begin{tabular}{|c|c|c|}
\hline $\begin{array}{l}\text { Comparison } \\
\text { Element }\end{array}$ & Social Cartography (Cartesian or not) & $\begin{array}{c}\text { Institutional Cartography } \\
\text { (Cartesian) }\end{array}$ \\
\hline Territory & $\begin{array}{l}\text { It represents the variables that are important for each } \\
\text { territory, since the self-recognition of the participating } \\
\text { community. }\end{array}$ & $\begin{array}{l}\text { It represents territories, } \\
\text { since modernity has been } \\
\text { defined as a priority for } \\
\text { the definition of nation- } \\
\text { state. }\end{array}$ \\
\hline Method & $\begin{array}{l}\text { Qualitative procedures where the community is the } \\
\text { main actor. Among them, there are oral language and } \\
\text { symbolic representation. }\end{array}$ & $\begin{array}{l}\text { Use of rigid instruments } \\
\text { to count on a given } \\
\text { information and statistical } \\
\text { methodologies. }\end{array}$ \\
\hline $\begin{array}{l}\text { Political } \\
\text { Position }\end{array}$ & There is a clear intention and political stance. & $\begin{array}{l}\text { It admits an apparent } \\
\text { objectivity and impartiality } \\
\text { of the data obtained. }\end{array}$ \\
\hline Power & $\begin{array}{l}\text { It legitimizes a process in which the interests of the } \\
\text { community are recognized as the engine of social } \\
\text { processes. Thus, one becomes aware of the power of } \\
\text { self-determination and transformation of the territory. }\end{array}$ & $\begin{array}{l}\text { Only institutional or } \\
\text { business interests are } \\
\text { taken into account. }\end{array}$ \\
\hline $\begin{array}{l}\text { Space } \\
\text { representation }\end{array}$ & $\begin{array}{l}\text { Combination of perceived, conceived and lived } \\
\text { space. Representations of the relations (networks of } \\
\text { strengthening, flows) that conform a territory. }\end{array}$ & $\begin{array}{l}\text { Representation of } \\
\text { perceived (Euclidean) } \\
\text { space where } \\
\text { georeferencing prevails. }\end{array}$ \\
\hline Methodology & $\begin{array}{l}\text { Qualitative and participatory methods where the } \\
\text { community and agents contribute: in the joint } \\
\text { elaboration of the map, the collective knowledge is } \\
\text { perpetuated; in the cultural environment, which is } \\
\text { mediated by the needs of the community, and the } \\
\text { potentialities of the territory to be represented. }\end{array}$ & $\begin{array}{l}\text { Quantitative methods. } \\
\text { Group of experts. They } \\
\text { represent the interest of } \\
\text { the institution and the } \\
\text { State. }\end{array}$ \\
\hline
\end{tabular}




\begin{tabular}{|l|l|l|}
\hline $\begin{array}{c}\text { Comparison } \\
\text { Element }\end{array}$ & \multicolumn{1}{|c|}{ Social Cartography (Cartesian or not) } & $\begin{array}{l}\text { Institutional Cartography } \\
\text { (Cartesian) }\end{array}$ \\
\hline Runtime & $\begin{array}{l}\text { The use of qualitative methodologies leads to a more } \\
\text { expensive work, but with less exclusive results. }\end{array}$ & $\begin{array}{l}\text { There are standard } \\
\text { procedures, which are } \\
\text { easily systematized. }\end{array}$ \\
\hline Systematization & $\begin{array}{l}\text { Systematization is incipient. It is necessary to } \\
\text { implement some documentation system of the } \\
\text { information collected. }\end{array}$ & $\begin{array}{l}\text { It continues to work on } \\
\text { software sophistication } \\
\text { and systematization } \\
\text { policies. }\end{array}$ \\
\hline Scale & $\begin{array}{l}\text { Defined by the level of participation. Usually detailed } \\
\text { scales. }\end{array}$ & $\begin{array}{l}\text { Level of aggregation. } \\
\text { Various scales and levels of } \\
\text { generalization. }\end{array}$ \\
\hline
\end{tabular}

Source: Adapted from Lobatón (2009).

It is noteworthy that in the case of social cartography the community is able to recognize its territory differently compared to the institutional one, but the latter can offer a better systematization for the measurement and analysis. In any case, although conventional cartography allows data about the territory to be worked on at different scales by specialists, there is a difficulty on the part of the community to understand how these data originate.

\section{CHARACTERISTICS OF THE ITATIAIA RURAL SETTLEMENT PROJECT, MINAS GERAIS, BRAZIL}

Created in 2004, the Itatiaia Settlement Project has 38 families distributed in their lots with an average area of each parcel around 41.1550bu in the municipality of João Pinheiro, in Minas Gerais, Brazil. The Legal Reserve area corresponds to $431.964 \mathrm{bu}$, approximately $21 \%$ of the total area of the rural settlement and the permanent conservation areas correspond to $81.1889 \mathrm{bu}$, plus the effective permanent preservation area of 32.464bu. Moreover, the rural settlement has a community planting area of about $42 \mathrm{bu}$, as well as a community area for headquarters and another for the corral.

According to the diagnosis pointed out by the Participative Rural diagnosis (PRD), the Itatiaia is on thick packs of clayey sediments, originally of yellow and reddish-brown color, in addition to a gravel area. The exploitation of this soil happens in the form of pastures and crops of short cycle and, or long, concerning the management level A and regular in the levels B and, or C. The distribution of the vegetation in the Itatiaia is predominance of areas of Cerrado Strictu sensu. In the area of the rural settlement, there are two paths, but they are not responsible for water supply in the houses, this comes from cisterns and wells.

Thus, in order to develop a mapping methodology, the researchers and authors of this work contacted the president of the Rural Producers' Association of the Itatiaia Rural Settlement Project to clarify how the studies would be conducted and if it would be possible to have the participation of the residents. The positive answer of the settlers on the execution of the field research, it was decided, at first, by a meeting, as a way to awaken and foment collective agreements between the researchers and settlers, as well as clarifying the following steps.

An important observation is about the condition of the researcher as an external element that must be inserted in the reality of the group in order to understand not only the local reality 
from their theoretical and documentary reading about that reality but also of the settlers. Furthermore, work involving participatory processes also involves an exchange of knowledge and mutual trust surrounding collectively negotiated agreements.

\section{METHODOLOGICAL PROCEDURES: THE FIELDWORK}

The field work tried to test the insertion of social cartography in the elaboration of participatory maps constructed by the community, so that this new methodology can generate greater efficiency in the collection of georeferenced data. In addition, the field work was supported by a manual with the steps for the elaboration of georeferenced participatory maps. The schematic (Figure 1) presents the steps of the research that were used so that this new methodology was developed and tested.

Figure 1 - Research Stages in the Itatiaia Settlement Project, João Pinheiro, MG

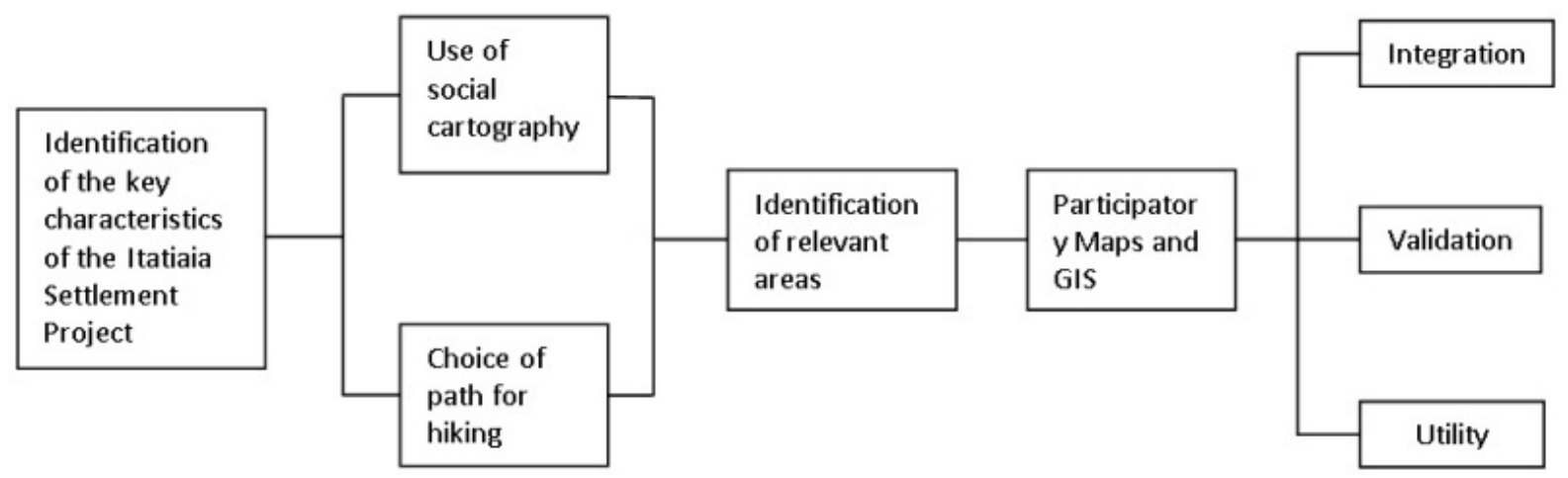

Source: Research data. Prepared by the authors.

Through the participatory mapping proposed by the Participatory Rural Diagnosis, the fieldwork was directed in 5 phases so that the methodology of social cartography was incorporated into the practice of participatory approaches, they are:

Phase 1- Identification of characteristics;

Phase 2- Elaboration of the participatory map (PRD tools);

Phase 3- Training in the use of GPS (Global Position System);

Phase 4-Construction of the georeferenced participatory map; and

Phase 5- Integration, validity and usefulness of the methodology of social cartography.

In the phase 1, which consisted of identifying the characteristics of the Itatiaia Rural Settlement Project, was the preparation of the fieldwork, through the collection of secondary information about the area studied, the maps already elaborated by INCRA were obtained during the PRD. At this stage, key informants were identified and selected and they contributed to the entire action-research process that was developed in the rural settlement.

After definition of those participating in the process of the participatory maps construction, the phase 2, which was the construction of the maps through Participatory Rural Diagnosis, started. At this stage, it was identified what kind of action could be developed with the rural settled community, thus choosing to make a map that mainly involved aspects of the physical environment, such as the use of the soil, type of vegetation and a wider view of the landscape in the eyes of whom live there. 
The participatory mapping technique (PRD) made it possible to collect data on the physical environment and the occupation of the spaces in the projects, while at the same time they served to train the settlers in the construction of social cartography. These moments were used in the present investigation to systematize the local knowledge regarding the conditions of the physical environment.

Throughout the elaboration of the maps, the concern was to count on perceptions and knowledge of all the segments of the community - men and women, old and young. At this moment, it was discussed with the participants the location of landscape components: rivers, mountains, community areas, boundaries of lots, areas of legal reserve and permanent preservation, etc. In addition, a cross-sectional course was conducted within the rural settlement with key informants to observe and record the different systems of land production and the use of the in the family lots. After this stage, the process in which the participants could identify the critical areas of the rural settlement, while making reference to the information that represents the map elaborated by the community.

In order to construct the participatory georeferenced map, the settlers had a qualification on the use of GPS, so that everyone could understand basic concepts such as scale, orientation, location and coordinates, as well as a knowledge about geographic space that would allow them to read and decode the maps elaborated by them. It should be noted, however, that this research required the identification in the rural settlement of people with greater interest and formal knowledge needed for the use of GPS, which training was the fieldwork phase 3.

Successively, in the phase 4 of the field work began, which corresponds to the mapping of the settlement and its natural resources with the construction of a cartographic representation of the living and working space, with the objective of creating a graphic vision and the knowledge that the settlers have of their surroundings and of the existing resources (Figures 2 and 3). Furthermore, the research proposed, prior to the beginning of the fieldwork, the creation of a protocol with the operational routines for the elaboration of the georeferenced community maps, which was tested, complemented and reformulated throughout the work.

Figures 2 and 3 - Settlers elaborating the map with data obtained by social cartography
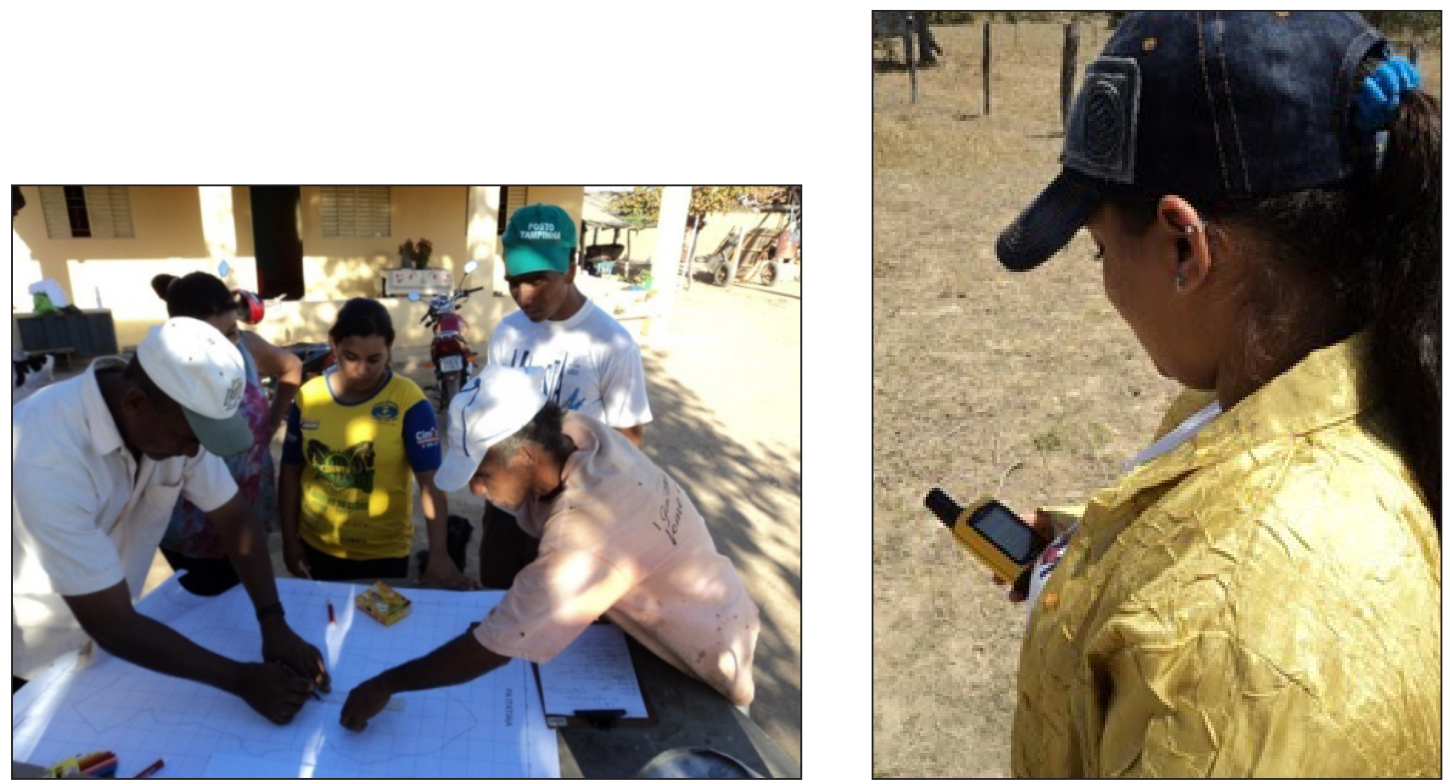

Source: Field survey data. 
The last phase was the integration of the georeferenced participatory map into a Geographic Information System, in which the generated components, the settlers formulated recommendations on the decision-making about natural resources and how they could intervene on it. The integration of the georeferenced participatory maps in a GIS was done with the use of free software and enabled the definition of criteria for its interpretation. The validation of the data collection technique was obtained by gathering the GIS product that integrated the elements identified by the community as a spatial reference.

Figure 4 - Points collected by the community inserted in the GIS

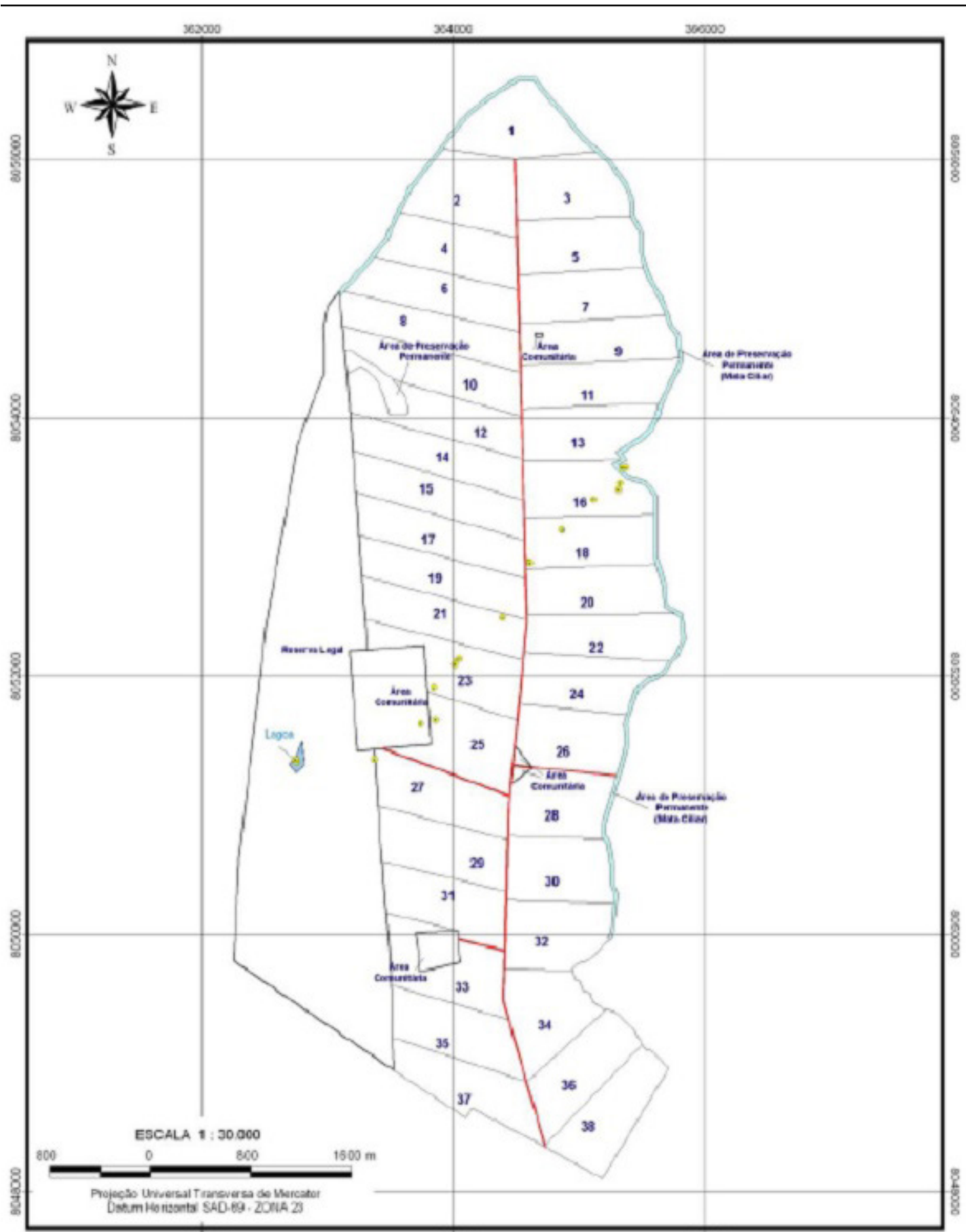

Source: Research data. Prepared by the authors. 
There is also the possibility that the identified elements are located in the wrong way from a georeferential point of view, so we correct the errors and allow a relation of the data generated by other types of spatial reference data. The utility stage, however, pointed out areas for the use of the technique tested.

The social cartography as a method that incorporates the participation of the actors in the decision making about the use of the territory is a recent proposal, especially when considered its use in agrarian reform projects, demanding a study that validates in this context as indicated by Milagres, Ferreira Neto and Sousa (2013). Thus, it is possible to affirm that the use of this methodological tool in the reality of the rural settlements contributes from the dynamics of creation of the projects, to the construction of monitoring mechanisms on the use and occupation of the parceled areas existing in these projects

The importance of this study consisted in the observation that in the territorial organization of projects it is necessary that in addition to considering the definition of size, number of families, productive capacity and regularity of the route, local and spatial knowledge should be considered from the point of view of the community.

In addition to the formalities required by the agencies responsible for agrarian reform policy, the method proposed here, if used, may allow a better understanding of the social relations present in the territory, by making it possible to identify the consequences of decision-making when considering the specificities of the community.

It was also noticed that the lack of access to technology by the community as well as low level of schooling can hinder the process, but it does not prevent the use of the method. Thus, the basis of analysis of this work was not dispensed the formal knowledge of the settlers, even in the initial phase. However, it should be emphasized that local knowledge stood out in relation to formal knowledge as also cited by Chambers (2006) in one of his works.

It was also understood that whenever the social mapping technique incorporated into PRD is used it is necessary to train the tool on the public involved. Even with a manual on the routines for the elaboration of the participatory georeferenced map (Figure 5), it makes necessary the presence of the researcher (facilitator agent) in the orientation and in the work of cartographic education. Despite the ease of using and collecting the points with GPS, both groups chose to check manually annotated data and not resort to technology. 
Figure 5 - Participative Map of Itatiaia without the use of GPS

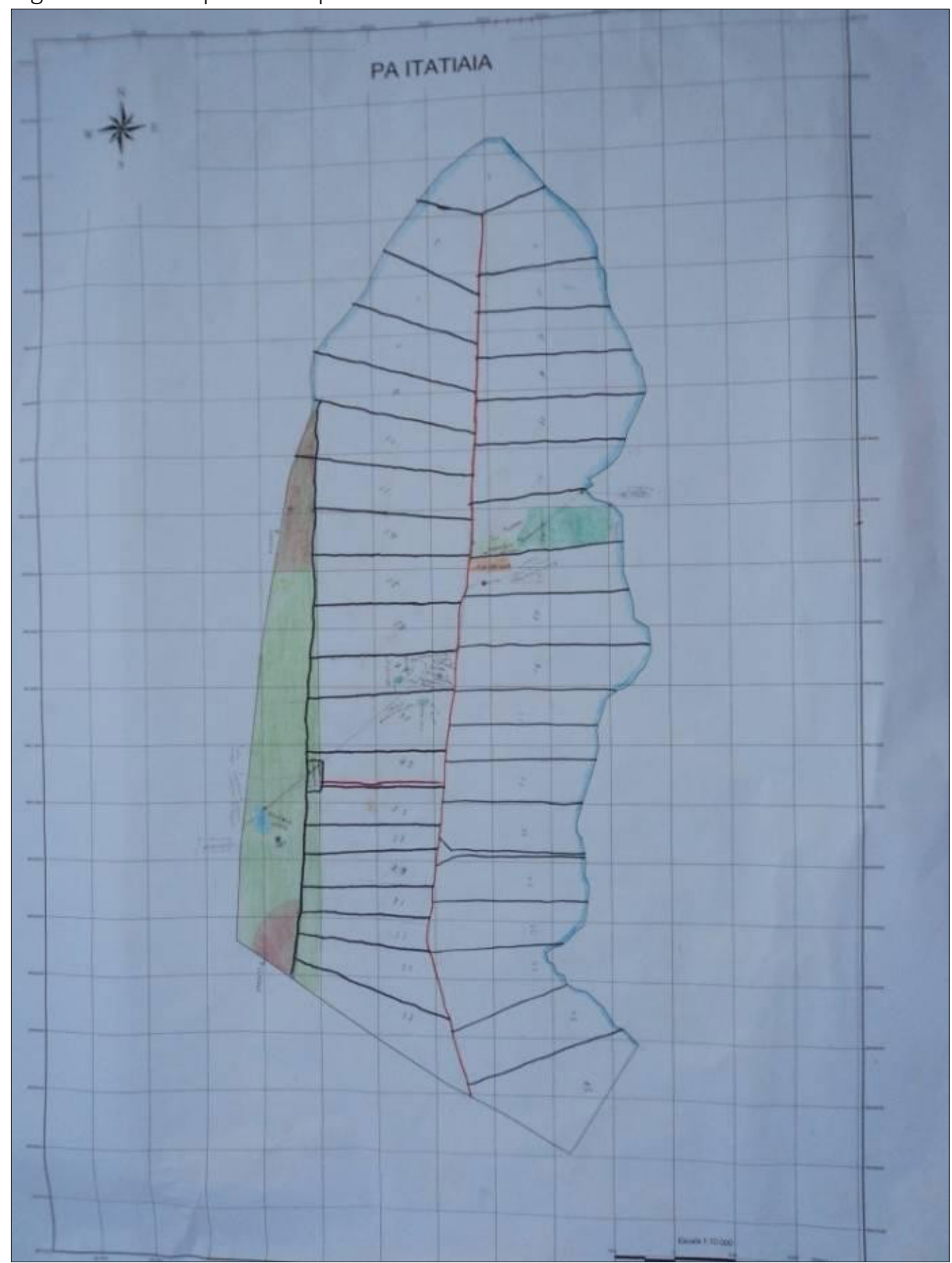

Source: Field survey data.

The technique made it possible to create a graphic view of the settlers' knowledge of their surroundings and of the existing resources. Thus, through the principles of participatory mapping proposed by the PRD and the insertion of social cartography as a method for the elaboration of the maps, the participants were able to elaborate a georeferenced participatory map on the land use and spatial occupation of the lots.

The Itatiaia settlement is a project that has always been valued the aspects of associativism and participation of the families, this perhaps was a positive point in the application of the technique, in which there is habituality in making collective decisions. 
The use of social cartography together with the PRD techniques allowed validation, at the level of participation, that the methodology facilitated the empowerment of the participants in the territorial representation of the rural settlement. Moreover, at the technical level its applicability adjusts to local capacities and allows both technical researchers and other participants to benefit from a democratic process. Therefore, the power of participation provides a way to give voice to the excluded, enabling them to express and analyze their problems and priorities (CHAMBERS; BLACKBURN, 1996). On the other hand, there are restrictions on the use of GIS by the community, most of the time it does not have computers or even a training to use GIS programs.

\section{CONCLUSIONS}

In the case of rural settlements, it is necessary to discuss participatory approaches, especially with regard to the representation of the territory, where the settlers, acting as agents can act by offering their participation for the actions to be performed. The georeferenced participatory mapping allows each member of the community to draw the space where they live as well as, if inserted within a perspective of local development, allowing the participants to improve management and decision-making in the rural settlement, thus obtaining control over the changes that may occur in the territory.

The use of social cartography alongside with the PRD techniques allowed validation, at the level of participation, that the methodology facilitated the empowerment of the participants in the territorial representation of the rural settlement. In addition, at the technical level, its applicability adjusts to local capabilities and provides to both technicians and other participants the benefits of a more democratic process.

\section{REFERENCES}

ANDRADE, H.; SANTAMARÍA, G. Cartografía social: el mapa como instrumento y metodología de la planeación participativa. Fundación Aldeas, 2018. Available at: http://fundaaldeas.org/web/index. php/articulos/49-cartografia-social-el-mapa-como-instrumento-y-metodologia-de-la-planeacionparticipativa.

BERNIER, P. Y. et al. Mapping local effects of forest properties on fire risk across Canada. Forests, v. 7, n. 8, p. 157-68, 2016.

BROSE, M. Introdução. In: BROSE, M. (Org.). Metodologia participativa: uma introdução a 29 instrumentos. Porto Alegre: Tomo Editorial, 2001.

CADAG, J.; GAILLARD, J. C. Integrating knowledge and actions in disaster risk reduction: the contribution of participatory mapping. Royal Geographical Society, v. 44, n. 1, p. 100-9, 2012.

CHAMBERS, R. Participatory mapping and geographic information systems: whose map? Who is empowered and who disempowered? Who gains and who loses? The Electronic Journal of Information Systems in Developing Countries, v. 25, n. 2, p. 1-11, 2006.

CHAMBERS, R. Famer first: innovation and agriculture research. London: Intermediate Technology, 1993.

CHAMBERS, R.; BLACKBURN, J. The power of participation: PRA and policy. IDS Policy Briefing, n. 7, p. 1-4, 1996. 
DIAS, M. M. Uma abordagem introdutória sobre concepções e práticas da extensão rural no Brasil. In: Relatório de Avaliação e Capacitação dos Técnicos do Programa de Assessoria Técnica, Social e Ambiental - ATES. Belo Horizonte: INCRA, 2006.

DINIZ, F. H. Produção de leite com qualidade em áreas de assentamento: proposições de intervenção como inovação. 2007. Dissertation (Master in Rural Extension)- Federal University of Viçosa, Viçosa, MG, Brazil, 2007.

DWAMENA, E.; BANAYNAL, R.; KEMAUSUOR, F. Participatory three dimensional model mapping (P3dm): expanding rural horizons and decision making for food security planning, climate change adaptation and flood risk reduction in Ghana. Research Journal of Agricultural Science, v. 43, n. 4, p. 186-95, 2011.

FERREIRA NETO, J. A.; MILAGRES, C. S. F.; SOUSA, D. N. O uso do aplicativo SOTER e da cartografia social na organização territorial em projetos de reforma agrária. In: FERREIRA NETO, J. A.; SOUSA, D. N.; MILAGRES, C. S. F. (Org.). Recursos naturais, sistemas de informação geográfica e processos sociais. Viçosa, MG: UFV, 2010.

FERREIRA NETO, J. A.; SOUSA, D. N.; CARDOSO, P. O.; MILAGRES, C. S. F. A população local e a percepção dos impactos dos assentamentos rurais. Revista Brasileira de Gestão e Desenvolvimento Regional, Taubaté, SP, v. 8, n. 1, p. 153-64, Jan./Apr. 2012.

GAILLARD, C.; HORE, K.; CADAG, J. R. D. Participatory mapping for disaster risk reduction: a review. Globe, n. 76, p. 31- 8, 2015.

GIBBON, D. Farming system research/extension: background, concepts, experience and networking. In: DENTON, J. G.; McGREGOR, M. J. (Org.). Rural and farming system analysis: european perspectives. Tucson, EUA: CAB International, 1994.

HERRERA, J. Cartografia social. Córdoba: Ed. Universidad Nacional Cordoba, 2009. p. 3-21.

HILBURN, A. M. Participatory risk mapping of garbage-related issues in a rural mexican municipality. Geographical Review, v. 105, n. 1, p. 41-60, 2015.

KIENBERGER, S. Participatory mapping of flood hazard risk in Munamicua, District of Búzi, Mozambique. Journal of Maps, v. 10, n. 2, p. 269-75, 2014.

LOBATON, S. N. Reflexiones sobre Sistemas de Información Geográfica Participativos (sigp) y cartografía social. Cuadernos de Geografía: Revista Colombiana de Geografía, n. 18, p. 9-23, 2009.

MCCALL, M. PGIS-PSP-IK-(CB)NRM: applying Participatory-GIS and participatory mapping to participatory spatial planning and to local-level land \& land resources management utilising indigenous \& local spatial knowledge. 2006. Available at: https://bit.ly/3f3y6Pu

MILAGRES, C. S. F.; SOUSA, D. N.; FERREIRA NETO, J. A. 'Traços que nos representam': o desenho infantil na construção da imagem de um assentamento rural. Humanidades \& Inovação, Brasília, v. 4, n. 2, p. 275-84, 2017.

MILAGRES, C. S. F.; MOURA, R. A; FERREIRA NETO, J. A. O uso e manejo dos recursos naturais na Amazônia Brasileira: a organização social e produtiva do PDS Nova Bonal. Mundo Agrario, La Plata, Argentina, v. 15, n. 29, p. 1-14, 2014.

MILAGRES, C. S. F.; FERREIRA NETO, J. A.; SOUSA, D. N. El uso de la cartografia social en la dinámica de creación de los mapas de organización territorial en proyectos de reforma agraria. Revista do Departamento de Geografia, São Paulo, v. 25, p. 253-62, 2013. 
MILAGRES, C. S. F.; PIZZIO, A.; SOUSA, D. N.; RODRIGUES, W.; CANÇADO, A. C. A Pnater como mecanismo de justiça social para a agricultura familiar. Cadernos de Ciência \& Tecnologia, Brasília, v. 35, n. 3, p. 45370, Sept./Dec. 2018.

REICHEL, C. Participatory mapping of local disaster risk reduction knowledge: an example from Switzerland. International Journal of Disaster Risk Science, v. 5, n. 1, p. 41-54, 2014.

ROBINSON, C. J.; MACLEAN, K.; HILL, R.; BOCK, E.; RIST, P. Participatory mapping to negotiate indigenous knowledge used to assess environmental risk. Sustainability Science, v. 11, n. 1, p. 115-26, 2016.

SANTOS JUNIOR, E. C. O ordenamento territorial em assentamentos rurais: uma análise utilizando algoritmos genéticos. 2007. Dissertation (Master in Rural Extension)- Federal University of Viçosa, Viçosa, MG, Brazil, 2007.

SOARES, J. L. N. A organização territorial de assentamentos rurais para atender a legislação ambiental da Amazônia. Campo-Território: Revista de Geografia Agrária, Uberlândia, MG, v. 3, n. 6, p. 143-55, 2008.

WEBBER, A. D. Using participatory risk mapping (PRM) to identify and understand people's perceptions of crop loss to animals in Uganda. PLoS ONE, v. 9, n. 7, e102912, 2014.

\section{About the authors:}

Cleiton Silva Ferreira Milagres: Doctor in Regional Development from the Federal University of Tocantins (UFT). Adjunct Professor I (UFT) in the course of Technology in Cooperative Management, campus Araguaína. E-mail: cleiton.milagres@uft.edu.br, Orcid: http://orcid.org/0000-0002-5651-4292

José Ambrósio Ferreira Neto: Post-doctor at LABORATE at the University of Santiago de Compostela, Lugo, Galicia, Spain. PhD in Development, Agriculture and Society by the Federal Rural University of Rio de Janeiro (UFRRJ). Full Professor at the Federal University of Viçosa (UFV). E-mail: ambrosio2@ufv.br, Orcid: http://orcid.org/0000-0002-1173-4582

Diego Neves de Sousa: Doctor in Rural Development from the Federal University of Rio Grande do Sul (UFRGS). Analyst at Embrapa Pesca e Aquicultura. E-mail: diego.sousa@embrapa.br, Orcid: http://orcid.org/0000-0003-3124-5150 